\title{
Brain enzyme activities after intracerebroventricular injection of streptozotocin in rats receiving acetyl-L- carnitine
}

Citation for published version (APA):

Terwel, D., Prickaerts, J., Meng, F., \& Jolles, J. (1995). Brain enzyme activities after

intracerebroventricular injection of streptozotocin in rats receiving acetyl-L-carnitine. European Journal of Pharmacology, 287(1), 65-71. https://doi.org/10.1016/0014-2999(95)00475-4

Document status and date:

Published: 01/01/1995

DOI:

10.1016/0014-2999(95)00475-4

Document Version:

Publisher's PDF, also known as Version of record

Please check the document version of this publication:

- A submitted manuscript is the version of the article upon submission and before peer-review. There can be important differences between the submitted version and the official published version of record.

People interested in the research are advised to contact the author for the final version of the publication, or visit the DOI to the publisher's website.

- The final author version and the galley proof are versions of the publication after peer review.

- The final published version features the final layout of the paper including the volume, issue and page numbers.

Link to publication

\footnotetext{
General rights rights.

- You may freely distribute the URL identifying the publication in the public portal. please follow below link for the End User Agreement:

www.umlib.nl/taverne-license

Take down policy

If you believe that this document breaches copyright please contact us at:

repository@maastrichtuniversity.nl

providing details and we will investigate your claim.
}

Copyright and moral rights for the publications made accessible in the public portal are retained by the authors and/or other copyright owners and it is a condition of accessing publications that users recognise and abide by the legal requirements associated with these

- Users may download and print one copy of any publication from the public portal for the purpose of private study or research.

- You may not further distribute the material or use it for any profit-making activity or commercial gain

If the publication is distributed under the terms of Article $25 \mathrm{fa}$ of the Dutch Copyright Act, indicated by the "Taverne" license above, 


\title{
Brain enzyme activities after intracerebroventricular injection of streptozotocin in rats receiving acetyl-L-carnitine
}

\author{
Dirk Terwel *, Jos Prickaerts, Fanping Meng, Jellemer Jolles \\ European Graduate School for Neuroscience i.f., Department of Psychiatry and Neuropsychology, University of Limburg, P.O. Box 616, \\ 6200 MD Maastricht, Netherlands
}

Received 27 July 1995; accepted 1 August 1995

\begin{abstract}
Intracerebroventricular (i.c.v.) injection of streptozotocin has been introduced as a means to inhibit glucose utilization in the rat brain, and to induce changes in neurotransmitter systems and behavior which resemble those seen in Alzheimer's disease. In this study, enzyme activities previously investigated in Alzheimer's disease (peptidases, dehydrogenases and acetyltransferases) were measured in the septum and hippocampus of control and streptozotocin-treated rats. Streptozotocin-treated rats receiving acetyl-L-carnitine were also included in the experiments, to assess possible neuroprotective effects of this substance. All enzyme activities in the septum were affected by streptozotocin, with the exception of choline acetyltransferase activity. By contrast, choline acetyltransferase activity was the only enzyme activity affected in the hippocampus. The weight of the septum was reduced in streptozotocin-treated animals. These findings indicate that i.c.v. injection of streptozotocin causes septal damage and enzymatic changes that do not closely resemble those seen in Alzheimer's disease, which are more specific. Acetyl-L-carnitine partly prevented this damage, as reflected by an attenuation of the streptozotocin-induced decrease in hippocampal choline acetyltransferase activity. This finding indicates that streptozotocin-treated rats may be valuable to test possible neuroprotective effects of drugs.
\end{abstract}

Keywords: Streptozotocin; Acetyl-L-carnitine; Brain; Alzheimer's disease; Oxidative stress

\section{Introduction}

Recently, Nitsch and Hoyer (1991) introduced intracerebroventricular (i.c.v.) injection of streptozotocin as a means to reduce brain glucose utilization. Besides a reduced glucose utilization after i.c.v. injection of streptozotocin, cholinergic and monoaminergic deficits and behavioral impairments have been observed (Ding et al., 1992; Hellweg et al., 1992; Blokland and Jolles, 1993, 1994). These deficits have been suggested to resemble those of Alzheimer's disease and, therefore, steptozotocin treatment was assumed to be of relevance to investigate pathogenetic changes involved in Alzheimer's disease (Nitsch et al., 1989; Blokland and

\footnotetext{
" Corresponding author. Department of Psychiatry and Neuropsychology, P.O. Box 616, 6200 MD Maastricht, The Netherlands. Tel. 31 (43) 881023; fax 31 (43) 671096.
}

Jolles, 1993; Plaschke and Hoyer, 1993). The mechanism through which streptozotocin causes its effects on the brain has not been investigated as yet. Hoyer and collaborators speculated that its action on the central nervous system might be similar to its peripheral action, i.e. the destruction of insulin-secreting cells or interference with the insulin receptor system (Nitsch et al., 1989; Nitsch and Hoyer, 1991; Plaschke and Hoyer, 1993). Systemic administration of streptozotocin is used to induce diabetes mellitus in experimental animals (Rakieten et al., 1963). Pancreatic $\beta$-cells are selectively destroyed by streptozotocin (Rakieten et al., 1963), although the selective vulnerability of these cells to streptozotocin is not entirely understood. Several studies have demonstrated that inhibitors of poly-ADP ribosylation, which is stimulated by single-strand DNA breaks, decrease the effect of streptozotocin on pancreatic $\beta$-cells (e.g. Dulin and Wyse, 1969; Bolaffi et al., 1987). This suggests that streptozotocin causes DNA 
damage, which is in accordance with the finding that streptozotocin generates DNA-damaging free radicals in cultures of pancreatic islets (Takasu et al., 1991).

The present study addresses the question whether changes in enzyme activities as observed in Alzheimer's disease are also observed after i.c.v. injection of streptozotocin. Thus, the possible relevance of the streptozotocin-treated rat as a model for Alzheimer's disease was studied. Several enzyme activities previously studied in Alzheimer's disease (Davies, 1979; Kalaria and Harik, 1992; Mastrogiacomo et al., 1993; Terwel et al., 1992, 1994) were measured in the septum and hippocampus three weeks after i.c.v. injection of streptozotocin or saline. The enzyme activities measured in the studies were those of prolyl endopeptidase, $\alpha$-ketoglutarate dehydrogenase, carnitine acetyltransferase and choline acetyltransferase, which are affected in Alzheimer's disease, and those of aminopeptidase and glutamate dehydrogenase, which are not affected in Alzheimer's disease. Choline acetyltransferase activity was used as a marker of cholinergic neurons, which die or shrink in Alzheimer's disease. The other enzyme activities are of a ubiquitous nature. The present study also addresses the question whether in the brain $\alpha$-ketoglutarate dehydrogenase is selectively affected by streptozotocin as compared to glutamate dehydrogenase, which has been shown to be the case in pancreatic $\beta$-cells (Rasschaert et al., 1992).

L-Carnitine and its acetylated form, acetyl-L-carnitine, are endogenous substances in various organs, including the brain (Bieber, 1988). L-Carnitine has a role in the $\beta$-oxidation by mitochondria of organs such as liver and muscle. This role of $\mathrm{L}$-carnitine is of minor importance in the brain, since the brain almost exclusively depends on the oxidation of glucose to meet its energy demands. However, L-carnitine and acetyl-Lcarnitine may be involved in the regulation of metabolic pathways in the brain (and other organs) by having an influence on the regeneration of $\mathrm{CoASH}$ and modulation of the level of acetyl-CoASH in the mitochondria. In addition, acetyl-L-carnitine may have a role as a precursor of acetylcholine, by providing the acetyl moiety for acetylcholine synthesis (White and Scates, 1990).

Chronic treatment with acetyl-L-carnitine has been shown to prevent impaired neuronal functioning in aged rats, both at the neurochemical level (Napoleone et al., 1990; Patacchioli et al. 1989; Taglialatela et al. 1994) and at the behavioral level (Barnes et al., 1990; Caprioli et al, 1990; Ghirardi et al., 1988, 1992). Moreover, it has been found that chronic treatment with acetyl-L-carnitine increases cholinergic functioning after fimbria-fornix transection (Piovesan et al. 1994), and attenuates behavioral deficits induced by i.c.v. treatment with cyanide (Blokland et al., 1993) or streptozotocin (Prickaerts et al., 1995). However, no uniform explanation has been offered to explain these neuroprotective effects of acetyl-L-carnitine. As neuronal functioning may be affected after streptozotocin treatment, the effects of chronic treatment with acetylL-carnitine on the enzyme activities mentioned were also evaluated in the streptozotocin-treated rats.

\section{Materials and methods}

\subsection{Animals}

For the first experiment 23 male Lewis rats of 18 months of age were used. The rats were divided over three groups of seven to nine animals. One group of rats was given acetyl-L-carnitine $(75 \mathrm{mg} / \mathrm{kg}$ per day) in the drinking fluid ( $0.1 \%$ saccharine). After 2 weeks on acetyl-L-carnitine the rats were anesthetized with pentobarbital $(60 \mathrm{mg} / \mathrm{kg}$, i.p.) and placed in a stereotaxic frame. A skin incision was made to free the skull and two holes were drilled above the lateral ventricles. The animals were given an injection of $2 \mu \mathrm{l}$ of streptozotocin solution in each lateral ventricle (total dose 1.5 $\mathrm{mg} / \mathrm{kg}$ body weight). The stereotaxic coordinates were $-0.8 \mathrm{~mm}$ anterior, $1.55 \mathrm{~mm}$ lateral and $-3.8 \mathrm{~mm}$ ventral from bregma (Paxinos and Watson, 1988). Streptozotocin was dissolved in saline just prior to injection. Another group of rats was not given acetylL-carnitine in the drinking fluid, but received injections of streptozotocin only. A third group of animals received injections with saline. 3 weeks after injection the animals were decapitated and the brains were removed from the skull in a cold room for dissection of the septum and hippocampus. For the second experiment 16 rats were used, divided over two groups of eight animals. The rats were treated in the same manner as in the first experiment, except that none of the rats was treated with acetyl-L-carnitine.

\subsection{Enzyme assays}

Brain tissues were homogenized in 19 volumes of 50 $\mathrm{mM}$ sodium phosphate ( $\mathrm{pH}$ 7.4). Part of the homogenates was centrifuged at high speed to obtain particle-free fractions. In both experiments prolyl endopeptidase, aminopeptidase and choline acetyltransferase activities were determined. In addition, carnitine acetyltransferase activity was determined in the first experiment and $\alpha$-ketoglutarate dehydrogenase, and glutamate dehydrogenase activities in the second experiment. All enzyme activities were not determined in a single experiment because of insufficient material.

\subsubsection{Prolyl endopeptidase}

Prolyl endopeptidase activity was determined spectrophotometrically with $N$-succinyl-Gly-Pro-Leu-GlyPro-7-amido-4-methylcoumarin as substrate. The sub- 
strate $(0.1 \mathrm{mM})$ was incubated with $10 \mu \mathrm{l}$ cytosol in 200 $\mu \mathrm{l}$ of a buffer consisting of $50 \mathrm{mM}$ Tris (pH 7.4), $1 \mathrm{mM}$ DTT and $1 \mathrm{mM}$ EDTA. at $37^{\circ} \mathrm{C}$. After $1 \mathrm{~h}$ of incubation the reaction was stopped by the addition of $0.3 \mathrm{ml}$ $1 \mathrm{M}$ acetic acid. Extinction was measured at a wavelength of $373 \mathrm{~nm}$.

\subsubsection{Aminopeptidase}

Aminopeptidase activity was measured with alanine $p$-nitroanilide as substrate. The substrate $(0.5 \mathrm{mM})$ was incubated with $10 \mu \mathrm{l}$ cytosol in $200 \mu \mathrm{l} 50 \mathrm{mM}$ Tris $(\mathrm{pH}$ 7.4) at $37^{\circ} \mathrm{C}$. After 30 min of incubation the reaction was stopped by the addition of $0.3 \mathrm{ml}$ ethanol. Extinction was measured at a wavelength of $410 \mathrm{~nm}$.

\subsection{3. $\alpha$-Ketoglutarate dehydrogenase}

$\alpha$-Ketoglutarate dehydrogenase activity was determined in the homogenates according to the procedure of Lai and Cooper (1986).

\subsubsection{Glutamate dehydrogenase}

Glutamate dehydrogenase activity was determined spectrophotometrically. The reaction mixture consisted of $50 \mathrm{mM}$ Tris $(\mathrm{pH} 8.0), 2.5 \mathrm{mM}$ EDTA, $100 \mathrm{mM}$ ammonium acetate, $0.2 \mathrm{mM} \mathrm{NADH}, 1 \mathrm{mM}$ ADP, 7 $\mathrm{mM} \alpha$-ketoglutarate, and $20 \mu \mathrm{l} 2 \%$ homogenate in a final volume of $1 \mathrm{ml}$. The reaction, at ambient temperature, was started by the addition of $\alpha$-ketoglutarate. The disappearance of NADH was monitored at a wavelength of $340 \mathrm{~nm}$. To calculate enzyme activity a correction was made for the change in extinction in the absence of $\alpha$-ketoglutarate.

\subsubsection{Choline acetyltransferase and carnitine acetyltrans- ferase}

Choline acetyltransferase activity was measured in the homogenates according to the method of Fonnum (1975). The method for the determination of carnitine acetyltransferase activity was identical to the method for the determination of choline acetyltransferase activity, except that L-carnitine hydrochloride was used as substrate instead of choline chloride and the reaction was stopped with $10 \mathrm{mM}$ phosphate $(\mathrm{pH} 3.0)$ instead of $14 \%$ trichloroacetic acicl.

\subsection{Statistics}

Data of the first experiment were subjected to a one-way analysis of variance with treatment as the dependent variable. Treatment effects between the three experimental groups were evaluated in more detail by using Student-Newman-Keuls test. Treatment effects in the second experiment were assessed by using Student's $t$-test. Relationships between measures were assessed by calculating Pearson's correlation coefficient $(R)$.

\section{Results}

\subsection{Experiment 1}

Septum weights \pm S.E.M. (mg) were $17.0 \pm 1.0,9.2$ \pm 1.3 , and $11.9 \pm 1.9$ in the control, the streptozotocininjected and the acetyl-L-carnitine-treated, streptozotocin-injected rats, respectively. The weight of the septum was reduced after injection of streptozotocin in both the animals treated with acetyl-L-carnitine and the untreated animals $(P<0.01)$. The weight of the hippocampus was unchanged (data not shown).

The enzyme activities in the septum of the saline-injected, the streptozotocin-injected and the acetyl-Lcarnitine-treated, streptozotocin-injected rats are given in Table 1. The three experimental groups differed in septal prolyl endopeptidase activity $(P<0.05)$, aminopeptidase activity $(P<0.05)$ and carnitine acetyltransferase activity $(P<0.01)$. Septal choline acetyltransferase activity only tended to be different between the groups $(0.05<P<0.1)$. Post hoc analysis revealed that prolyl endopeptidase, aminopeptidase and carnitine acetyltransferase activities were reduced in the septum of the streptozotocin-injected animals, whereas choline acetyltransferase activity was not changed. Treatment with acetyl-L-carnitine did not prevent prolyl endopeptidase and carnitine acetyltransferase activities from being reduced. Aminopeptidase activity was spared by treatment with acetyl-L-carnitine. However, septal choline acetyltransferase activity of the acetyl-Lcarnitine-treated, streptozotocin-injected rats was even

Table 1

Enzyme activities in the septum of saline-injected, streptozotocin-injected and acetyl-L-carnitine-treated, streptozotocin-injected rats of experiment 1

\begin{tabular}{|c|c|c|c|}
\hline $\begin{array}{l}\text { Enzyme activity } \\
\left(\mathrm{nmol} \cdot \mathrm{h}^{-1} \cdot \mathrm{mg}^{-1} \text { protein }\right)\end{array}$ & Control & Streptozotocin & $\begin{array}{l}\text { Acetyl-L-carnitine, } \\
\text { streptozotocin }\end{array}$ \\
\hline $\begin{array}{l}\text { Prolyl endopeptidase } \\
\text { Aminopeptidase } \\
\text { Carnitine acetyltransferase } \\
\text { Choline acetyltransferase }\end{array}$ & $\begin{array}{r}72 \pm 5^{\mathrm{a}} \\
568 \pm 24^{\mathrm{a}} \\
1219 \pm 31^{\mathrm{a}} \\
100 \pm 9^{\mathrm{a}}\end{array}$ & $\begin{array}{l}46 \pm 5^{b} \\
486 \pm 17^{b} \\
858 \pm 70^{b} \\
110 \pm 7^{a, b}\end{array}$ & $\begin{array}{l}56 \pm 6^{\mathrm{a}, \mathrm{b}} \\
564 \pm 24^{\mathrm{a}} \\
949 \pm 71^{\mathrm{b}} \\
135 \pm 13^{\mathrm{b}}\end{array}$ \\
\hline
\end{tabular}

Data represent means \pm S.E.M. Means of enzyme activities with the same superscript are not different (Student-Newman-Keuls test, $P<0.05$ ). 
Table 2

Enzyme activities in the hippocampus of saline-injected, streptozotocin-injected and acetyl-L-carnitine-treated, streptozotocin-injected rats of experiment 1

\begin{tabular}{llll}
\hline $\begin{array}{l}\text { Enzyme activity } \\
\left(\mathrm{nmol} \cdot \mathrm{h}^{-1} \cdot \mathrm{mg}^{-1} \text { protein }\right)\end{array}$ & Control & Streptozotocin & $\begin{array}{l}\text { Acetyl-L-carnitine, } \\
\text { streptozotocin }\end{array}$ \\
\hline Prolyl endopeptidase & $125 \pm 5^{\mathrm{a}}$ & $123 \pm 7^{\mathrm{a}}$ & $127 \pm 4^{\mathrm{a}}$ \\
Aminopeptidase & $569 \pm 28^{\mathrm{a}}$ & $535 \pm 25^{\mathrm{a}}$ & $621 \pm 41^{\mathrm{a}}$ \\
Carnitine acetyltransferase & $854 \pm 27^{\mathrm{a}}$ & $786 \pm 35^{\mathrm{a}}$ & $857 \pm 21^{\mathrm{a}}$ \\
Choline acetyltransferase & $117 \pm 3^{\mathrm{a}}$ & $44 \pm 13^{\mathrm{b}}$ & $84 \pm 16^{\mathrm{a}}$
\end{tabular}

Data represent means \pm S.E.M. Means of enzyme activities with the same superscript are not different (Student-Newman-Keuls test, $P<0.05$ ).

Table 3

Pearson's correlation coefficients for data from experiment 1 on septum weight and enzyme activities

\begin{tabular}{lrl}
\hline Enzyme activity & $R$ & $P$ \\
\hline Prolyl endopeptidase & 0.838 & $<0.001$ \\
Aminopeptidase & 0.594 & $<0.01$ \\
Carnitine acetyltransferase & 0.754 & $<0.001$ \\
Choline acetyltransferase & -0.272 & $>0.05$ \\
\hline
\end{tabular}

Table 4

Enzyme activities in the septum of saline-injected and streptozotocin-injected rats from experiment 2

\begin{tabular}{lrr}
\hline $\begin{array}{l}\text { Enzyme activity } \\
\left(\mathrm{nmol} \cdot \mathrm{h}^{-1} \cdot \mathrm{mg}^{-1} \text { protein }\right)\end{array}$ & Control & Streptozotocin \\
\hline Prolyl endopeptidase & $66 \pm 3$ & $35 \pm 6^{* *}$ \\
Aminopeptidase & $567 \pm 12$ & $418 \pm 29^{* *}$ \\
$\alpha$-Ketoglutarate dehydrogenase & $545 \pm 33$ & $306 \pm 27^{* *}$ \\
Glutamate dehydrogenase & $5938 \pm 218$ & $2602 \pm 149^{* *}$ \\
\hline
\end{tabular}

Data represent means \pm S.E.M. Asterisks indicate differences with respect to control $(t$-test, $P<0.001)$.

Table 5

Enzyme activities in the hippocampus of saline-injected and streptozotocin-injected rats from experiment 2

\begin{tabular}{lrr}
\hline $\begin{array}{l}\text { Enzyme activity } \\
\left(\mathrm{nmol} \cdot \mathrm{h}^{-1} \cdot \mathrm{mg}^{-1} \text { protein) }\right.\end{array}$ & Control & Streptozotocin \\
\hline Prolyl endopeptidase & $137 \pm 10$ & $128 \pm 8$ \\
Aminopeptidase & $682 \pm 48$ & $607 \pm 26$ \\
$\alpha$-Ketoglutarate dehydrogenase & $615 \pm 45$ & $650 \pm 49$ \\
Glutamate dehydrogenase & $8106 \pm 308$ & $8065 \pm 279$ \\
Choline acetyltransferase & $92 \pm 2$ & $39 \pm 13$
\end{tabular}

Data represent means \pm S.E.M. Asterisk indicates a difference with respect to control $(t$-test, $P<0.01)$.

Table 6

Pearson's correlation coefficients for data from experiment 2 on septum weight and enzyme activities

\begin{tabular}{lll}
\hline Enzyme activity & $R$ & $P$ \\
\hline Prolyl endopeptidase & 0.977 & $<0.001$ \\
Aminopeptidase & 0.901 & $<0.001$ \\
$\alpha$-Ketoglutarate dehydrogenase & 0.691 & $<0.01$ \\
Glutamate dehydrogenase & 0.845 & $<0.001$ \\
\hline
\end{tabular}

higher than that of the saline-injected rats. In the hippocampus of all experimental groups prolyl endopeptidase, aminopeptidase, and carnitine acetyltransferase activities were unaffected (see Table 2, $P$ values $>0.05$ ), whereas choline acetyltransferase activity was affected $(P<0.01)$. Post hoc analysis showed that treatment with acetyl-L-carnitine attenuated the decrease in choline acetyltransferase activity in the hippocampus elicited by streptozotocin.

High correlations were found between septum weight and enzyme activities, except choline acetyltransferase activity (see Table 3 ). The correlation between choline acetyltransferase activity in the septum and that in the hippocampus was poor $(R=-0.093, P$ $>0.05$ ), but the correlation between septum weight and choline acetyltransferase activity in the hippocampus was high $(R=0.832, P<0.001)$.

\subsection{Experiment 2}

Septum weights \pm S.E.M. (mg) were $17.2 \pm 0.5$ and $7.9 \pm 1.5$ in the control and the streptozotocin-injected rats, respectively. The weight of the septum was reduced after injection of streptozotocin $(P<0.001)$. The weight of the hippocampus was unaffected (data not shown).

Prolyl endopeptidase, aminopeptidase, $\alpha$-ketoglutarate dehydrogenase, and glutamate dehydrogenase activities in the septum were reduced after injection of streptozotocin (see Table 4), whereas in the hippocampus these enzyme activities were not affected by streptozotocin. However, choline acetyltransferase activity in the hippocampus of the streptozotocin-injected rats was reduced compared with that of the control animals (see Table 5).

High correlations were found between septum weight and enzyme activities (see Table 6). The correlation between septum weight and choline acetyltransferase activity in the hippocampus was high ( $R=$ $0.917, P<0.001$ ).

\section{Discussion}

In the present study the effects of streptozotocin on enzyme activities in the septum and hippocampus of 
control rats and of rats treated with acetyl-L-carnitine were studied. Streptozotocin affected enzyme activities in the septum rather indiscriminately, except choline acetyltransferase activity, whereas it affected only choline acetyltransferase activity in the hippocampus. Acetyl-L-carnitine did not spare all the enzyme activities in the septum, but seemed to preserve the cholinergic function in the hippocampus to some extent. The general effect of streptozotocin on enzyme activities in the septum contrasts with its reportedly selective effects on enzyme activities in pancreatic $\beta$-cells (Rasschaert et al., 1992). This difference might be explained by the possibility that streptozotocin may have caused cell death in the septum, whereas enzyme activities in pancreatic $\beta$-cells have been measured in cells surviving the insult by streptozotocin.

The above findings suggest that cholinergic neurons in the septum were relatively spared from the degenerative effects of streptozotocin. This does not necessarily mean that cholinergic neurons are less vulnerable to streptozotocin than other cells, since many of the noncholinergic cells in the septum are closer to the injection site than the cholinergic neurons. The relative sparing of the cholinergic neurons may have been enhanced by acetyl-L-carnitine. Histological and immunocytochemical studies are in progress to assess which brain structures are affected by streptozotocin.

Specific choline acetyltransferase activity in the septum was unaffected by streptozotocin, whereas specific choline acetyltransferase activity in the hippocampus was reduced. This seems surprising, since the hippocampus receives a cholinergic input from the septum. However, the septum weight was reduced, whereas the hippocampus weight was unaltered, so that in both structures total choline acetyltransferase activity was reduced. In addition, total choline acetyltransferase activities in these two structures were strongly correlated $(R=0.751, P<0.001)$. Therefore, the reduced choline acetyltransferase activity in the hippocampus can be explained by an effect of streptozotocin at the level of the septum.

Interestingly, choline acetyltransferase activity correlated highly with carnitine acetyltransferase activity in the hippocampus $(K=0.712, P<0.001)$, although this latter activity was not significantly reduced after injection of streptozotocin. In addition, hippocampal carnitine acetyltransferase activity correlated both with septal carnitine acetyltransferase activity $(R=0.499, P$ $<0.05)$ and with septum weight $(R=0.607, P<0.01)$. These correlations suggest that carnitine acetyltransferase may be linked to the septohippocampal pathway. This may have to do with the possibility that the enzyme is preferentially located in cholinergic nerve endings. This possibility is in accordance with some previous findings. First, lesion of the habenulointerpe- duncular tract has been shown to result in reduced activity of both carnitine acetyltransferase and choline acetyltransferase in the interpeduncular nucleus (Sterri and Fonnum, 1980). Second, it has been reported that nerve growth factor (NGF) increases both carnitine acetyltransferase and choline acetyltransferase activities in PC12 cells (White and Scates, 1991). Moreover, these results suggest that preferential localization of carnitine acetyltransferase in cholinergic terminals is a general phenomenon.

The fact that enzyme activities were affected rather indiscriminately in the septum together with a reduced weight of the septum suggests that streptozotocin acts as a non-selective neurotoxin near the site of injection. Hoyer and collaborators, who used the same dose of streptozotocin as used in this study, found rather widespread effects of streptozotocin on energy metabolism and neurotransmitter systems and ascribed these effects to a possible interference of streptozotocin with the action of insulin in the brain. However, our finding of septal degeneration is not in line with such a specific effect of streptozotocin on the action of insulin. The destruction of septal-hippocampal and septal-cortical connections may have contributed to the effects of streptozotocin in locations distant from the septum. Therefore, with respect to the mechanism of action of streptozotocin an alternative hypothesis may be formulated. Since it has been shown that streptozotocin causes its effects on pancreatic $\beta$-cells by the generation of hydrogen peroxide (Takasu et al., 1991), it can be hypothesized that streptozotocin does so in the central nervous system as well.

There is evidence that oxidative stress is important in the pathogenesis of Alzheimer's disease and other neurodegenerative diseases (reviewed by Olanow, 1993). This evidence is for the most part indirect, consisting of alterations in the accumulation of peroxidation products in tissues (Andorn et al., 1990; Palmer and Burns, 1994) and changes in the activity of enzymes sensitive to changes in redox status (Terwel et al., 1992; Morrison et al., 1993). Interestingly, it has recently been shown that $\beta$-amyloid peptide increases the production of oxygen free radicals by stimulating a NADPH oxidase-like activity or by an auto-oxidative process (Behl et al., 1994; Goodman et al., 1994). However, i.c.v. injection of streptozotocin caused a general decline in the enzyme activities determined, whereas in Alzheimer's disease some of these enzyme activities are reduced and others are not (Terwel et al., 1992; Mastrogiacomo et al., 1993). The effect of streptozotocin on the septum may have been too strong to mimic what is going on in Alzheimer's disease. In addition, the septum may not be the most appropriate area to induce Alzheimer's disease-like features, since brain areas other than the septum are affected by 
Alzheimer's disease. Future studies should investigate the effects of low doses of streptozotocin in brain areas that are affected in Alzheimer's disease.

Two effects of acetyl-L-carnitine reported in the literature may be of relevance to explain the positive effects of acetyl-L-carnitine on the septohippocampal cholinergic system. Firstly, acetyl-L-carnitine increases the binding of NGF to its receptor in aged rat central nervous system (Angelucci et al., 1988). Secondly, in PC12 cells acetyl-L-carnitine increases the synthesis of the NGF receptor (Taglialatela et al., 1992) and the subsequent internalization of NGF (Taglialatela et al., 1991), which is important in the action of NGF. Correspondingly, it has been found that acetyl-L-carnitine increases NGF levels and choline acetyltransferase activity in the central nervous system of fimbria-fornix transectioned rats (Piovesan et al., 1994) and aged rats (Taglialatela et al., 1994). Finally, the fact that NGF plays a role in oxidant homeostasis (Pan and PerezPolo, 1993) strengthens the possibility that NGF is involved in the neuroprotective effect of acetyl-Lcarnitine against the damaging effects of streptozotocin.

In conclusion, i.c.v. injection of streptozotocin causes structural damage in the septum. This damage causes enzymatic changes that do not closely resemble the more specific changes in enzyme activities as observed in Alzheimer's disease. Acetyl-L-carnitine partly prevents this damage, as reflected by an attenuation of the streptozotocin-induced decrease in hippocampal choline acetyltransferase activity. This finding indicates that streptozotocin-treated rats may be valuable to test neuroprotective effects of substances. Furthermore, it demonstrates that acetyl-L-carnitine has a neuroprotective action on cholinergic neurons. However, little is known about the neuroprotective effect of acetyl-Lcarnitine on non-cholinergic neurons. Injection of low doses of streptozotocin in brain sites other than the septum in combination with assessment of markers of specific neuronal populations may be a way to study the neuroprotective effects of acetyl-L-carnitine on non-cholinergic neurotransmitter systems.

\section{Acknowledgements}

We thank Sigma Tau Company (Pomezia, Italy) for financial support and for providing us with acetyl-Lcarnitine.

\section{References}

Andorn, A.C., R.S. Britton and B.R. Bacon, 1990, Evidence that lipid peroxidation and total iron are increased in Alzheimer's brain, Neurobiol, Aging 11, 316.
Angelucci, L., M.T. Ramacci, G. Taglialatela, C. Helsebosch, B. Morgan, K. Werrbach-Perez and J.R. Perez-Polo, 1988, Nerve growth factor binding in aged rat central nervous system: effect of acetyl-L-carnitine, J. Neurosci. Res. 20, 491.

Barnes, C.A., A.L. Markowska, D.K. Ingram, H. Kametani, E.L. Spangler, V.J. Lemken and D.S. Olton, 1990, Acetyl-L-carnitine 2: effects on learning and memory performance of aged rats in simple and complex mazes, Neurobiol. Aging 11, 499.

Behl, C., J.B. Davis, R. Lesley and D. Schubert, 1994, Hydrogen peroxide mediates amyloid $\beta$ protein toxicity, Cell 77, 817.

Bieber, L.L., 1988, Carnitine, Ann. Rev. Biochem. 57, 261.

Blokland, A. and J. Jolles, 1993, Spatial learning deficit and reduced hippocampal ChAT activity in rats after an i.c.v. injection of streptozotocin, Pharmacol. Biochem. Behav. 44, 491.

Blokland, A. and J. Jolles, 1994, Behavioral and biochemical effects of an i.c.v. injection of streptozotocin in old Lewis rats, Pharmocol. Biochem. Behav. 47, 833.

Blokland, A., J. Bothmer, W. Honig and J. Jolles, 1993, Behavioral and biochemical effects of acute central metabolic inhibition: effects of acetyl-L-carnitine, Eur. J. Pharmacol. 235, 275.

Bolaffi, J.L., S. Nagamatsu, J. Harris and G.M. Grodsky, 1987, Protection of thymidine, an inhibitor of polyadenosine diphosphate ribosylation, of streptozotocin inhibition of insulin secretion, Endocrinology 120, 2117.

Caprioli, A., O. Ghirardi, M.T. Ramacci and L. Angelucci, 1990, Age-dependent deficits in radial maze performance in the rat: effect of chronic treatment with acetyl-L-carnitine, Prog. Neuropsychopharmacol. Biol. Psychiat. 14, 359.

Davies, P., 1979, Neurotransmitter-related enzymes in senile dementia of the Alzheimer type. Brain Res. 171, 319.

Ding, A., R. Nitsch and S. Hoyer, 1992, Changes in brain monoaminergic neurotransmitter concentrations in rat after intracerebroventricular injection of streptozotocin, J. Cereb. Blood Flow Metab. 12, 103.

Dulin, W.E., B.M. Wyse, 1969, Studies on the ability of compounds to block diabetogenic activity of streptozotocin, Diabetes 18,459 .

Fonnum, F., 1975, A rapid radiochemical method for the determination of choline acetyltransferase, J. Neurochem. 24, 407.

Ghirardi, O., S. Milano, M.T. Ramacci and L. Angelucci, 1988, Effect of acetyl-L-carnitine chronic treatment on discrimination models in aged rats, Physiol. Behav. 44, 769.

Ghirardi, O., A. Caprioli, S. Milano, A. Giuliani, M.T. Ramacci and L. Angelucci, 1992, Active avoidance learning in old rats chronically treated with levocarnitine acetyl, Physiol. Behav. 52, 185.

Goodman, Y., M.R. Steiner, S.M. Steiner and M.P. Mattson, 1994, Nordihydroguaiaretic acid protects hippocampal neurons against amyloid $\beta$-peptide toxicity, and attenuates free radical and calcium accumulation, Brain. Res. 654, 171.

Hellweg, R., R. Nitsch, C. Hock, M. Jaksch and S. Hoyer, 1992, Nerve growth factor and choline acetyltransferase activity levels in the rat brain following experimental impairment of cerebral glucose and energy metabolism, J. Neurosci. Res. 31, 479.

Kalaria, R.N. and S.I. Harik, 1992, Carnitine acetyltransferase activity in the human brain and its microvessels is decreased in Alzheimer's disease, Ann. Neurol. 32, 583.

Lai, J.C.K. and A.J.L. Cooper, 1986, Brain $\alpha$-ketoglutarate dehydrogenase complex: kinetic properties, regional distribution, and effects of inhibitors, J. Neurochem. 47, 1376.

Mastrogiacomo, F., C. Bergeron and S.J. Kish, 1993, Brain $\alpha$-ketoglutarate dehydrogenase complex activity in Alzheimer's disease, J. Neurochem. 61, 2007.

Morrison, L.D., C. Bergeron and S.J. Kish, 1993, Brain S-adenosylmethionine decarboxylase activity is increased in Alzheimer's disease, Neurosci. Lett. 154, 141.

Napoleone, P., F. Ferrante, O. Chirardi, M.T. Ramacci and F. Amenta, 1990, Age-dependent nerve cell loss in the brain of 
Sprague-Dawley rats: effest of a long-term acetyl-L-carnitine treatment, Arch. Gerontol. Geriatr. 10, 173.

Nitsch, R. and S. Hoyer, 1991, Local action of the diabetogenic drug, streptozotocin, on glucose and energy metabolism, Neurosci. Lett. 128, 199.

Nitsch, R., C. Mayer and S. Hoyer, 1989, The intracerebroventricularly streptozotocin-treated rat: impairment of glucose metabolism resembles the alteration of carbohydrate metabolism of the brain in Alzheimer's disease, J. Neural Transm. 1 (P-D Section), 109.

Olanow, C.W., 1993, A radical hypothesis for neurodegeneration, Trends Pharmacol. Sci. 16, 439.

Palmer, A.M. and M.A. Burns, 1994, Selective increase in lipid peroxidation in the inferior temporal cortex in Alzheimer's disease, Brain Res. 645, 338.

Pan, Z. and R. Perez-Polo, 1993, Role of nerve growth factor in oxidant homeostasis: glutathione metabolism, J. Neurochem. 61, 713.

Patacchioli, F.R., F. Amenta. M.T. Ramacci, G. Taglialatela, S. Maccari and L. Angelucci, 1989, Acetyl-L-carnitine reduces the age dependent loss of adrenocorticoid receptors in the rat hippocampus: an autoradiographic study, J. Neurosci. Res. 23, 462.

Paxinos, G. and C. Watson, 1988, The rat brain in stereotaxic coordinates, 2nd edn. (Academic Press, Sydney).

Piovesan, P., L. Pacifici, G. Taglialatela, M.T. Ramacci and L. Angelucci, 1994, Acetyl-L-carnitine treatment increases choline acetyltransferase activity and NGF levels in the CNS of adult rats following total fimbria-fornix transection, Brain. Res. 633, 77.

Plaschke, K. and S. Hoyer, 1993, Action of the diabetogenic drug streptozotocin on glycolytic and glycogenolytic metabolism in adult rat brain cortex and hippocampus, Int. J. Dev. Neurosci. 11, 477.

Prickaerts, J., A. Blokland, W. Honig, F. Meng and J. Jolles, 1995, Spatial discrimination learning and choline acetyltransferase activity in streptozotocin-treated rats: effects of chronic treatment with acetyl-L-carnitine, Brain Res. 674, 142.

Rakieten, N., M.L. Rakieten and M.V. Nadkarni, 1963, Studies on the diabetogenic action of streptozotocin, Cancer Chemother. Rep. 29, 91.

Rasschaert, J., D.L. Eizirik and W.J. Malaisse, 1992, Long term in vitro effects of streptozotocin, interleukin-1, and high glucose concentration on the activity of mitochondrial dehydrogenases and the secretion of insulin in pancreatic islets, Endocrinology $130,3522$.

Sterri, S.H. and F. Fonnum, 1980, Acetyl-CoA synthesizing enzymes in cholinergic nerve terminals, J. Neurochem. 35, 249.

Taglialatela, G., L. Angelucci, M.T. Ramacci, K. Werbach-Perez, G.R. Jackson and J.R. Perez-Polo, 1991, Acetyl-L-carnitine enhances the response of PC12 cells to nerve growth factor, Dev. Brain. Res. 59, 221.

Taglialatela, G., L. Angelucci, M.T. Ramacci, K. Werrbach-Perez, G.R. Jackson and J.R. Perez-Polo, 1992, Stimulation of nerve growth factor receptor in $\mathrm{PC12}$ cells by acetyl-L-carnitine, Biochem. Pharmacol. 44, 577.

Taglialatela, G., D. Navarra, R. Cruciani, M.T. Ramacci, G.S. Alema and L. Angelucci, 1994, Acetyl-L-carnitine treatment increases nerve growth factor levels and choline acetyltransferase activity in the central nervous system of aged rats, Exp. Gerontol. 29, 1.

Takasu, N., I. Komiya, T. Asawa, Y. Nagasawa and T. Yamada 1991, Streptozotocin- and alloxan-induced $\mathrm{H}_{2} \mathrm{O}_{2}$ generation and DNA fragmentation in pancreatic islets, Diabetes 40, 1141.

Terwel, D., M. Markerink, J. Jolles, 1992, Peptidases are affected differently in neocortical regions of brains from patients with Alzheimer's disease, Dementia 3, 108.

Terwel, D., J. Bothmer, F. Meng, E. Wolf, M. Markerink and J. Jolles, 1994, Reduced enzyme activities in Alzheimer's disease are sensitive to hypoxia, Neurobiol. Aging 15 (Suppl. 1), S120.

White, H.L. and P.W. Scates, 1990, Acetyl-L-carnitine as a precursor of acetylcholine, Neurochem. Res. 15, 597.

White, H.L. and P.W. Scates, 1991, Stimulation of carnitine acetyltransferase in PC12 cells by nerve growth factor: relationship to choline acetyltransferase, Neurochem. Res. 16, 63. 